\title{
Comparative Antibacterial Study of Silver Nanoparticles Doped Activated Carbon Prepared by Different Methods
}

\author{
Pragya Pandey ${ }^{1}$, Bivek Karki ${ }^{1}$, Binod Lekhak ${ }^{2}$, Agni R. Koirala ${ }^{3}$, R. K. Sharma ${ }^{1,4}$, Hem R. Pant ${ }^{1,4 *}$ \\ ${ }^{1}$ Nanomaterials Lab, Department of Applied Sciences, Pulchowk Campus \\ Institute of Engineering, Tribhuvan University, Nepal \\ ${ }^{2}$ Central Department of Microbiology, Tribhuvan University, Kritipur, Nepal \\ ${ }^{3}$ Department of Chemistry, Sogang University, Shinsu-dong, Mapo-go, Seoul. Republic of Korea \\ ${ }^{4}$ Research Institute for Next Generation, Kalanki, Kathmandu, Nepal \\ *Corresponding author: hempant@ioe.edu.np
}

Received: Nov 2, 2018

Revised: Dec 24, 2018

Accepted: Dec 27, 2018

\begin{abstract}
Activated carbon is greatly used to adsorb toxic heavy metals from water bodies. Simultaneous removal of such pollutants and pathogenic impurities is essential for safe drinking water. In this study, silver nanoparticles (NPs) doped activated carbon (AC) composite was fabricated via hydrothermal technique and green synthesis technique using commercial activated carbon powder and silver nitrate solution. Several analytical techniques, including scanning electron microscopy (SEM), energy dispersive x-ray (EDX), X-ray diffraction (XRD) and Fourier-transform infrared spectroscopy (FTIR) confirmed the formation of silver nanoparticles on the surface and pores of AC. The prepared composite materials were accessed for their anti-bacterial property using Escherichia coli and Staphylococcus aureus and found that such materials have good antibacterial activity which shows that as fabricated composite can be used potentially for water treatment.
\end{abstract}

Keywords: Activated carbon, antibacterial activity, green synthesis, hydrothermal process, silver nanoparticles.

\section{Introduction}

Availability of safe drinking water is one of the biggest challenges in underdeveloped countries, as the number of infected population from water borne diseases (caused by pathogenic microorganisms) is significantly high. Almost a century ago, the rate of water borne diseases witnessed a pronounced decrease with the advent of sand filtration and chlorine disinfection, but it is yet not completely eliminated from various parts of the globe. Various chlorine-based disinfection methods currently in practice efficiently kill microbial pathogens but may produce harmful carcinogenic disinfection byproducts (DBPs) in presence of natural organic matter, anthropogenic contaminants, bromide, and iodide, which remain available in the water $[28,22]$. UV based water disinfection systems are costly and requires a power source to operate. In presence of natural organic matter, UV treatment however leads to formation of harmful byproducts and increases the concentration of byproducts further in presence of chlorine [5, 7]. Nowadays, reverse osmosis membranes have also been used for water disinfection. However, the membrane modules are very costly and prolonged use results 
in biofouling [10]. Therefore, it is important to re-evaluate conventional disinfection techniques and to innovate new approaches to obtain safe drinking water at a low cost.

Nanomaterials are excellent adsorbents, catalysts and sensors due to their large specific surface area and high reactivity. Various natural and engineering nanomaterials has shown strong antimicrobial properties, that include chitosan [25], silver nanoparticles [20], photocatalytic $\mathrm{TiO}_{2}[4$, 33], fullerol [1], aqueous fullerene nanoparticles [18], and carbon nanotubes [14]. In addition, due to their high anti-microbial activity, silver nanoparticles have also been used in clothing [31], food industry [3], cosmetics [16] and are projected as the future generation antimicrobial agents [27]. In the nanometer size range, the specific surface area of AgNPs increases significantly and they show a very high antibacterial activity compared to bulk one [26, 30, 31]. Ag-NP kills bacterial cells due to generation of reactive oxygen species (ROS) [24]. Direct application of silver nanoparticles might cause problems, as they have tendency to aggregate in aqueous media which gradually reduces their efficiency in long term. Hence the nanomaterials need host matrix to perform in better way. Currently, different porous matrices like, alginate beads [17], polyurethane foam [11], polymeric micro spheres [8], resin beads [21] have been used as a host for impregnation. However, activated carbon (AC) has already been widely used as a filtration media in most of the household filters for drinking water. Extremely high specific surface area and well-developed internal micro and meso pores of AC provides a high adsorption capacity and it also removes most of the inorganic and organic contaminants from drinking water [2]. Hence, AC was selected as a support matrix in the present work and Ag-NPs were synthesized and impregnated on AC, without affecting adsorption capacity of the native AC. Therefore, we have impregnated Ag-NP on porous supports for water disinfection, with the goal of producing drinkable water.

\section{Experimental}

\subsection{Materials}

Commercial activated carbon obtained from Fisher Scientific was used without further processing. Silver nitrate from Universal Chemicals, ammonium hydroxide $\left(\mathrm{NH}_{4} \mathrm{OH}, 25 \% \mathrm{NH}_{3}\right.$ in water) and ethanol from Fisher Scientific, poly (vinylpyrrolidone) (PVP, MW-5800) from Alfa Aesar, and locally available Aloe vera were used as received.

\subsection{Preparation of $\mathrm{Ag} / \mathrm{AC}$ composite}

\subsubsection{Hydrothermal Approach}

$\mathrm{Ag} / \mathrm{AC}$ composite was synthesized using one-step hydrothermal approach. Here, $1 \mathrm{ml}$ of ammonia was added to a $30 \mathrm{ml}$ aqueous solution containing $50 \mathrm{mg} \mathrm{AC}, 10 \mathrm{mg}$ of $\mathrm{AgNO}_{3}, 10 \mathrm{mg} \mathrm{PVP}$ and $5 \mathrm{ml}$ of ethanol followed by continuous stirring for $45 \mathrm{mins}$ using magnetic stirrer. The mixture was then transferred to autoclave for hydrothermal treatment at $130^{\circ} \mathrm{C}$ for 3 hours. The obtained composite was washed several times with distilled water and ethanol and was dried in oven at $30^{\circ} \mathrm{C}$ for 12 hours and at $80^{\circ} \mathrm{C}$ for 6 hours.

\subsubsection{Green Synthesis}

Aloe vera extract was prepared by boiling $30 \mathrm{~g}$ of thoroughly washed Aloe vera leaves which were then finely chopped and boiled in $100 \mathrm{ml}$ of distilled water for 20 minutes. $2.5 \mathrm{ml}$ of $30 \%$ ammonia solution was added to $5 \mathrm{ml}$ of $10^{-2} \mathrm{M} \mathrm{AgNO}_{3}$ solution followed by addition of $5 \mathrm{ml}$ of the Aloe vera extract. The concentration of $\mathrm{AgNO}_{3}$ was adjusted to $10^{-3} \mathrm{M}$ by making the final volume to 50 
$\mathrm{ml}$ with water. $30 \mathrm{mg} \mathrm{AC}$ was added to thus prepared solution and stirred for $24 \mathrm{hrs}$. The obtained composite was filtered and washed several times with distilled water and ethanol, and was dried at $130^{\circ} \mathrm{C}$ for $14 \mathrm{hrs}$.

\subsection{Characterization}

The surface morphology of activated carbon and as-synthesized composites were studied by filedemission scanning electron microscopy (FE-SEM, S-7400, Hitachi, Japan) and EDX was also performed using FE-SEM. Information about the crystallographic structure of as-synthesized composite was obtained using Rigaku X ray diffractometer (XRD, Rigaku, Japan) with $\mathrm{Cu} \mathrm{K} \alpha(\lambda$ $=1.540 \AA$ ) radiation over Bragg angles ranging from 5 to $90^{\circ}$. Fourier transform infrared (FT-IR) spectra of different samples were recorded by using an ABB Bomen MB100 spectrometer (Bomen, Canada).

\subsection{Antibacterial Property}

The antibacterial activity of different composites was studied separately for gram negative bacteria (Escherichia coli) and gram-positive bacteria (Staphylococcus aureus) as model microorganism. The experiments were conducted in sterilized test tubes containing $10 \mathrm{ml}$ sterilized distilled water containing E. coli suspension which was standardized to match McFarland (turbidity) standard in which the bacterial density was estimated to be $10^{8} \mathrm{CFU} / \mathrm{ml}$. Thus standardized suspension was diluted to obtain the bacterial density of $10^{7} \mathrm{CFU} / \mathrm{ml}$. The diluted suspension was then treated with $0.4 \mathrm{~g} / \mathrm{l}$ of different composites with continuous shaking. The tests were performed at room temperature for 120 mins. At given time intervals, $1 \mathrm{ml}$ suspension was collected and diluted appropriately by serial dilution in distilled water. To count the bacterial concentration agar plates prepared using nutrient agar were used. After incubation at $37^{\circ} \mathrm{C}$ for $24 \mathrm{hrs}$, the number of bacterial colonies was manually counted. Similar procedure was followed for S. aureus.

\section{Results and Discussions}

\subsection{Characterization of the Composite Particles}

FE-SEM images were used to investigate the morphology of commercial AC and as-synthesized $\mathrm{Ag}$ NPs doped AC composites. Fig. 1 shows the respective morphologies of pristine AC, Ag/AC composite via hydrothermal process and $\mathrm{Ag} / \mathrm{AC}$ composite via green synthesis. The image clearly shows surface modification of the AC. The particle size of Ag on the surface of AC composite prepared via green synthesis was roughly $80 \mathrm{~nm}$ to $200 \mathrm{~nm}$ and that prepared by hydrothermal process were of size ranging from $50 \mathrm{~nm}$ to $100 \mathrm{~nm}$. The EDX analysis of the composites showed the presence of silver along with the constituent elements of $\mathrm{AC}$, confirming the formation of composite particles.

Additionally, the molecular structures of different samples were investigated by FT-IR spectroscopy. Fig. 2 shows the FT-IR spectra of pristine AC and the prepared composite. The broad spectra observed between 2500 and $3300 \mathrm{~cm}^{-1}$ indicates the $\mathrm{O}-\mathrm{H}$ bond $[13,9]$. The broadening of IR band between 2500 and $3300 \mathrm{~cm}^{-1}$ for the composite is due to the $\mathrm{O}-\mathrm{H}$ bond as well as moisture absorbed by the composite. It can also be seen that the peaks of the composite at $3300 \mathrm{~cm}^{-1}$ shifted towards right indicating the interaction between $\mathrm{Ag}$ and $\mathrm{AC}$ [35]. The peaks near 1635 and $1053 \mathrm{~cm}^{-1}$ indicate the formation of silver nanoparticles $[29,6]$. Also, it is observed that the characteristic bands of AC did not shift after loading AgNPs which indicates the formation of the composite via 
van der Waals interactions [13]. Moreover, the appearance of same peak in pristine AC and the composites confirms the assembly of composites.
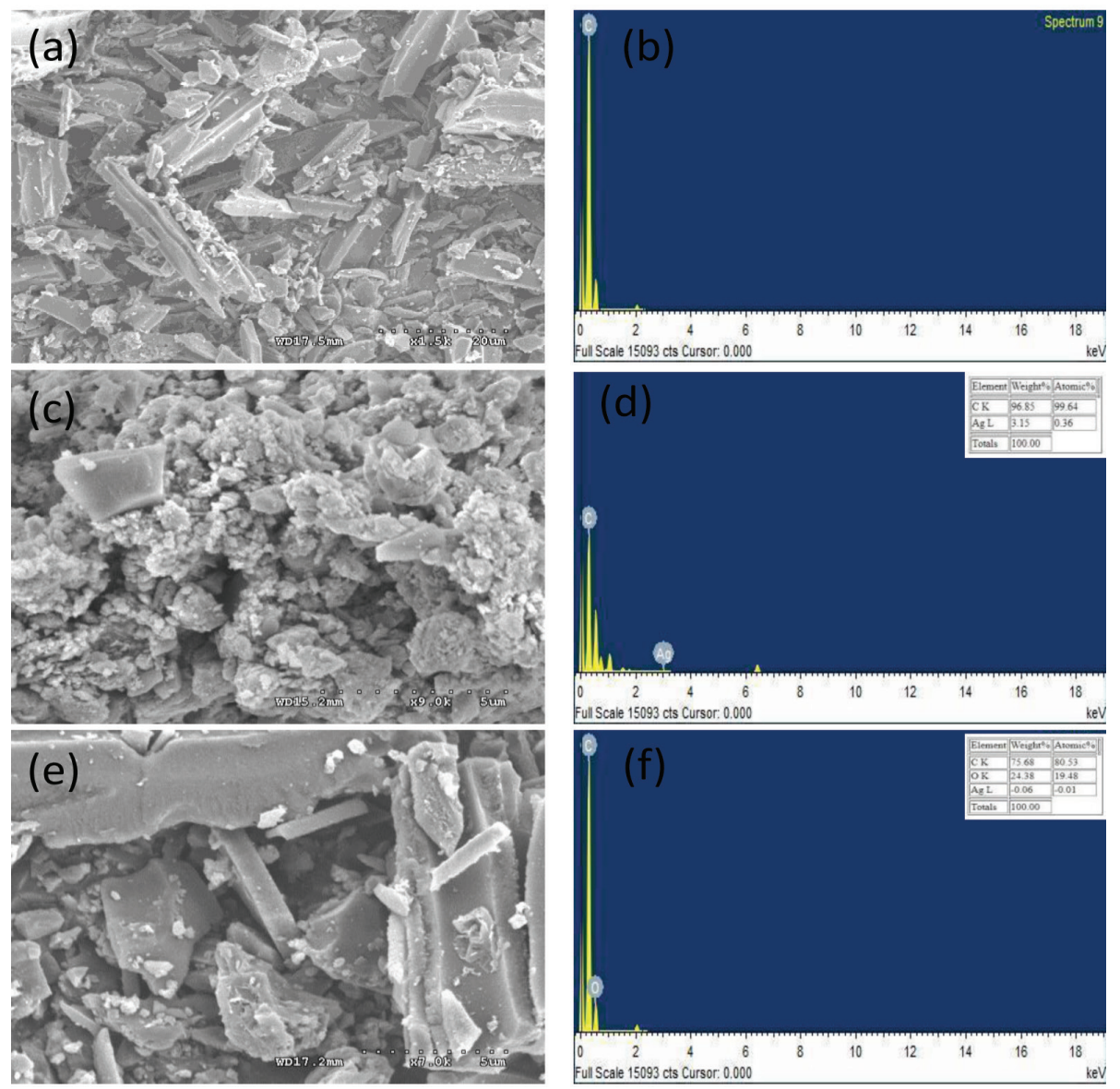

Fig. 1: FE-SEM image and EDX mapping of pristine $\mathrm{AC}(\mathrm{a}, \mathrm{b}), \mathrm{Ag} / \mathrm{AC}$ composite prepared via Hydrothermal Process(c, d) and Ag/AC composite prepared via Green Synthesis (e, f)

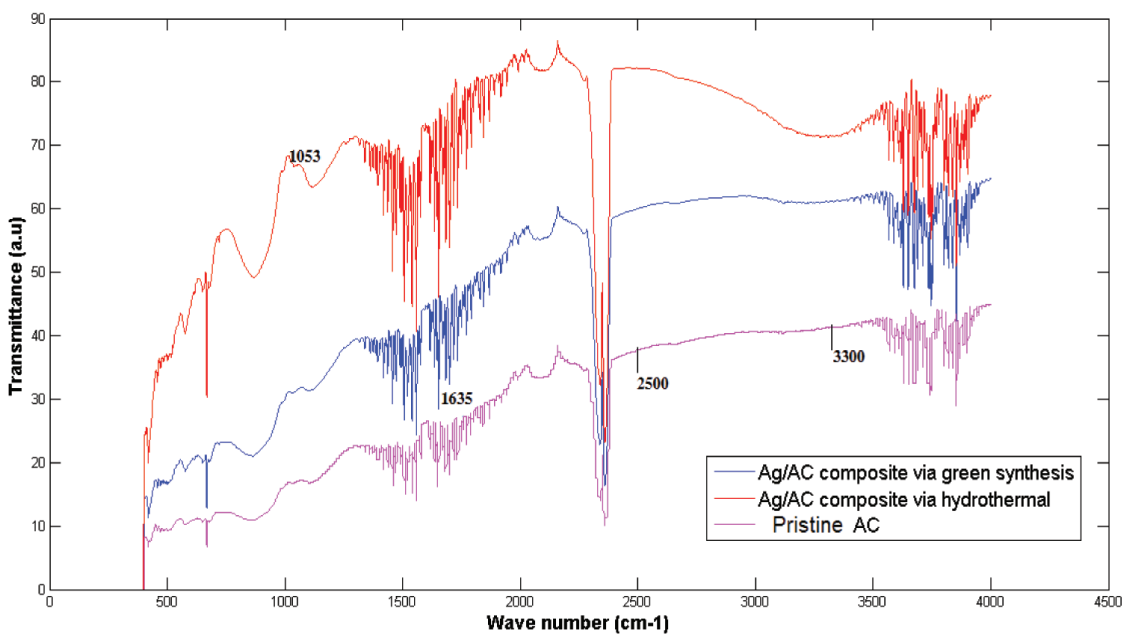

Fig. 2: FT-IR spectra of different samples 
Additionally, XRD analysis was performed to determine the crystal structure of the synthesized composite. Fig. 3 shows the XRD pattern of pristine AC and the Ag/AC composite. The pristine AC showed a mild hump ranging from 20 to 25 indicating the amorphous structure of AC. In addition, $\mathrm{Ag} / \mathrm{AC}$ composite showed the presence of Ag NPs with peaks at 2 theta $=27.51(210), 31.87(113)$, $38.2(111), 44.3(200), 56.56(240), 64.5(220), 66.26(226)$ and 77.4(311) that are characteristics of face centered cubic Ag NPs $[12,15]$.

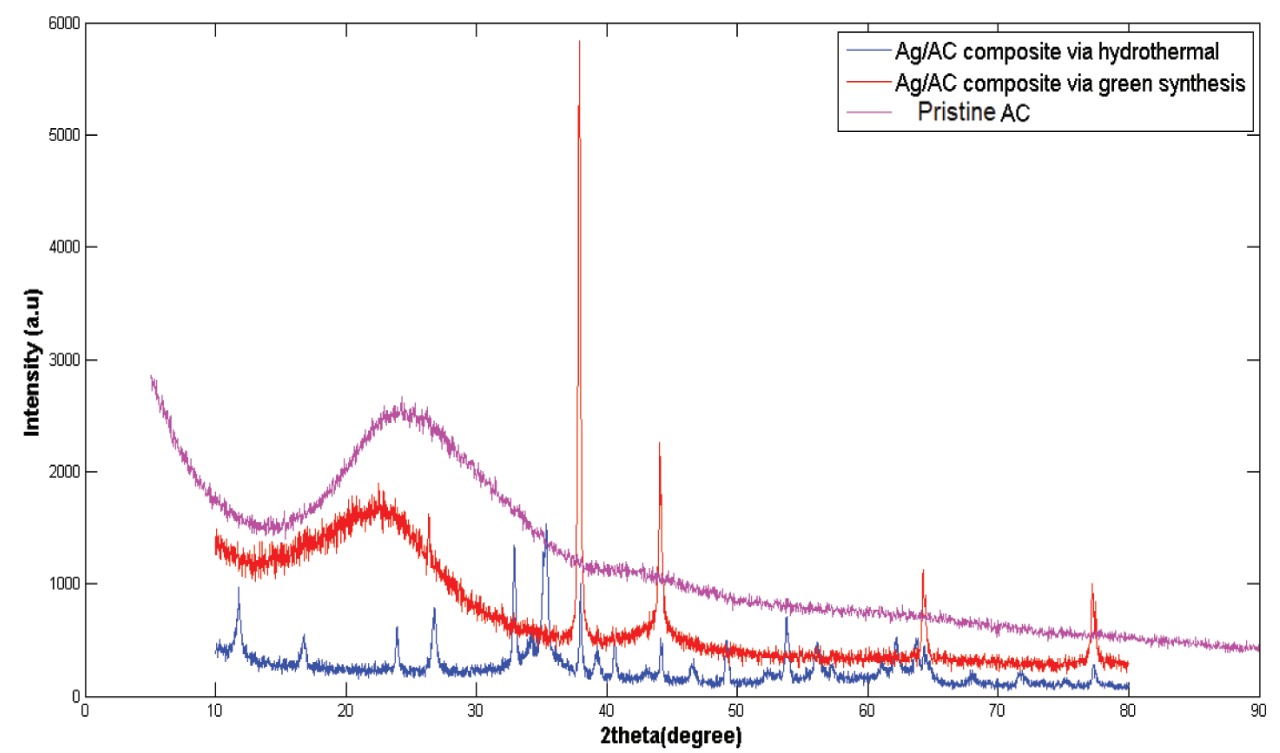

Fig. 3: XRD pattern of different samples

\subsection{Antibacterial activity}

The antibacterial behavior of the composite was tested against E. coli and S. aureus by carrying out bacterial colony count method. Fig. 4 shows the antibacterial efficiency of different samples. The efficiency of $\mathrm{Ag} / \mathrm{AC}$ composite was considerably higher than the pristine AC. The bacterial count in case of both composites (prepared hydrothermally and by green synthesis) decreased in similar way. In first hour, the hydrothermal $\mathrm{Ag} / \mathrm{AC}$ performed better than $\mathrm{Ag} / \mathrm{AC}$ composite prepared by green synthesis for E. coli. But ultimately at the end of 2 hours both samples reduced the E. coli count equally. In case of $S$. aureus, both samples performed in same way, except for $80^{\text {th }}$ to $100^{\text {th }}$ minute where the composite prepared by green synthesis performed better than hydrothermally prepared composite.

It has been reported that $\mathrm{Ag}^{+}$hinders DNA replication and inhibits the expression of ribosomal proteins and enzymes for ATP hydrolysis [34]. Ag NPs can directly damage bacterial cell membrane, Ag NPs appears to exert bactericidal activity through the release of Ag ions which increases membrane permeability including leakage of cellular content and disruption of DNA replication [19]. It is also reported that $\mathrm{Ag}$ NPs display the same mechanism as $\mathrm{Ag}^{+}$and create a redox imbalance, which causes extensive bacterial death [23]. These results confirmed the improved antibacterial activity of $\mathrm{Ag} / \mathrm{AC}$ composite. 

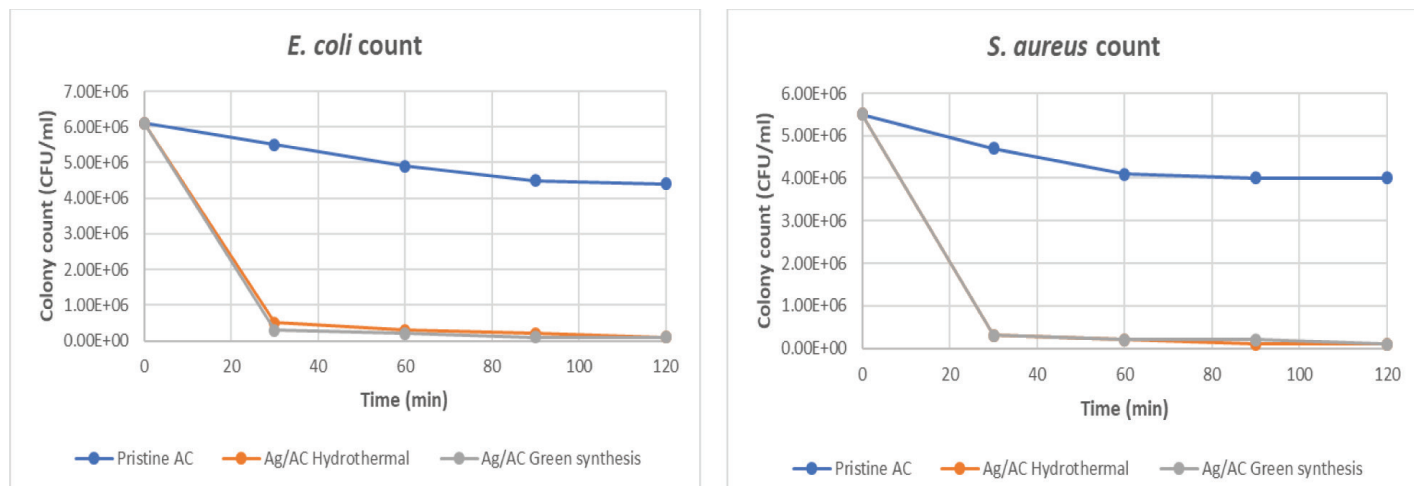

Fig. 4: Antibacterial activity of different samples against E. coli and S. aureus

\section{Conclusion}

The Ag/AC composites were synthesized by facile, one-pot hydrothermal process and also by green synthesis for comparative study. The prepared composites and pristine activated carbon were tested for their antibacterial efficiency. The composites showed remarkable performance for reduction in the number of bacterial counts. The methods used in this study for the fabrication of $\mathrm{Ag} / \mathrm{AC}$ composite are simple and effective while the materials used are non-hazardous which makes it possible to further expand the research work for tailoring the desired species into porous $\mathrm{AC}$ substrate to attain the desired property of the filter media. Therefore, it can be said that the $\mathrm{Ag}$ NPs incorporated AC prepared via facile methods is an economic and environment friendly material for water treatment.

Acknowledgment: The research work was supported by The World Academy of Science, Trieste, Italy (TWAS)/Swedish International Development Corporation Agency (Sida) (project number; 18-168RG/ CHE/AS_G-FR3240303651) and University Grant Commission, Nepal (project number; -CRG-74/74Engg-02). We are thankful to Department of Chemistry, Sogang University, Republic of Korea for characterizing the samples.

\section{References}

[1] Badireddy AR, Hotze EM, Chellam S, Alvarez P and Wiesner MR (2007), Inactivation of bacteriophages via photosensitization of fullerol nanoparticles, Environmental Science \& Technology, 41(18): 6627-6632.

[2] Brennan JK, Bandosz TJ, Thomson KT, and Gubbins KE(2001), Water in porous carbons, Colloids and surfaces A: Physicochemical and engineering aspects, 187: 539-568.

[3] Chaudhry Q and Castle L (2011), Food applications of nanotechnologies: an overview of opportunities and challenges for developing countries, Trends in Food Science \& Technology, 22(11): 595-603.

[4] Cho M, Chung H, Choi W and Yoon J (2005), Different inactivation behaviors of MS-2 phage and Escherichia coli in $\mathrm{TiO}_{2}$ photocatalytic disinfection, Applied and environmental microbiology, 71(1): 270-275.

[5] Choi Y and Choi YJ (2010), The effects of UV disinfection on drinking water quality in distribution systems, Water research, 44(1): 115-122. 
[6] Devaraj P, Kumari P, Aarti C andRenganathan A (2013), Synthesis and characterization of silver nanoparticles using cannonball leaves and their cytotoxic activity against MCF-7 cell line, Journal of nanotechnology.

[7] Dotson AD, Metz D and Linden KG (2010), UV/ $\mathrm{H}_{2} \mathrm{O}_{2}$ treatment of drinking water increases post-chlorination DBP formation, Water research, 44(12): 3703-3713.

[8] Gangadharan D, Harshvardan K, Gnanasekar G, Dixit D, Popat KM andAnand PS (2010), Polymeric microspheres containing silver nanoparticles as a bactericidal agent for water disinfection, Water research, 44(18): 5481-5487.

[9] Gotić M and Musić S (2007), Mössbauer, FT-IR and FE SEM investigation of iron oxides precipitated from FeSO4 solutions, Journal of Molecular Structure, 834: 445-453.

[10] Hsieh HP, Bhave RR and Fleming HL (1988), Microporous alumina membranes, Journal of membrane science, 39(3): 221-241.

[11] Jain and Pradeep T (2005), Potential of silver nanoparticle-coated polyurethane foam as an antibacterial water filter, Biotechnology and bioengineering, 90(1): 59-63.

[12] Joshi MK, Pant HR, Kim HJ, Kim JH and Kim CS(2014), One-pot synthesis of Ag-iron oxide/ reduced graphene oxide nanocomposite via hydrothermal treatment, Colloids and Surfaces A: Physicochemical and Engineering Aspects, 446: 102-108.

[13] Joshi MK, Pant HR, Liao N, Kim JH, Kim HJ, Park CH and Kim CS (2015), In-situ deposition of silver- iron oxide nanoparticles on the surface of fly ash for water purification, Journal of colloid and interface science, 453: 159-168.

[14] Kang S, Pinault M, Pfefferle LD and Elimelech M (2007), Single-walled carbon nanotubes exhibit strong antimicrobial activity, Langmuir, 23(17): 8670-8673.

[15] Karthik L, Kumar G, Kirthi AV, Rahuman AA and Rao KB (2014), Streptomyces sp. LK3 mediated synthesis of silver nanoparticles and its biomedical application, Bioprocess and biosystems engineering, 37(2): 261-267.

[16] Kokura S, Handa O, Takagi T, Ishikawa T, Naito Y and Yoshikawa T (2010), Silver nanoparticles as a safe preservative for use in cosmetics, Nanomedicine: Nanotechnology, Biology and Medicine, 6(4): 570-574.

[17] Lin S, Huang R, Cheng Y, Liu J, Lau BL and Wiesner MR (2013), Silver nanoparticle-alginate composite beads for point-of-use drinking water disinfection, Water research, 47(12): 39593965.

[18] Lyon DY, Adams LK, Falkner JC and Alvarez PJ (2006), Antibacterial activity of fullerene water suspensions: effects of preparation method and particle size, Environmental Science \& Technology, 40(14): 4360-4366.

[19] Marambio-Jones C, and Hoek, EM (2010), A review of the antibacterial effects of silver nanomaterials and potential implications for human health and the environment, Journal of Nanoparticle Research, 12(5): 1531-1551.

[20] Morones JR, Elechiguerra JL, Camacho A, Holt K, Kouri JB, Ramírez JT and Yacaman MJ (2005), The bactericidal effect of silver nanoparticles, Nanotechnology, 16(10): 2346.

[21] Mthombeni NH, Mpenyana-Monyatsi L, Onyango MS andMomba MN (2012), Breakthrough analysis for water disinfection using silver nanoparticles coated resin beads in fixed-bed column, Journal of hazardous materials, 217: 133-140.

[22] Nieuwenhuijsen MJ, Grellier J, Smith R, Iszatt N, Bennett J, Best Nand Toledano M (2009), The epidemiology and possible mechanisms of disinfection by-products in drinking 
water, Philosophical Transactions of the Royal Society of London A: Mathematical, Physical and Engineering Sciences, 367(1904): 4043-4076.

[23] Pant HR, Pant B, Sharma RK, Amarjargal A, Kim HJ, Park CH and Kim CS (2013), Antibacterial and photocatalytic properties of $\mathrm{Ag} / \mathrm{TiO} 2 / \mathrm{ZnOnano-flowers} \mathrm{prepared} \mathrm{by} \mathrm{facile} \mathrm{one-pot}$ hydrothermal process, Ceramics International, 39(2): 1503-1510.

[24] Park HJ, Kim JY, Kim J, Lee JH, Hahn JS, Gu MB, and Yoon J (2009), Silver-ion-mediated reactive oxygen species generation affecting bactericidal activity, Water research, 43(4): 10271032.

[25] Qi L, Xu Z, Jiang X, Hu C and Zou X (2004), Preparation and antibacterial activity of chitosan nanoparticles, Carbohydrate research, 339(16): 2693-2700.

[26] Rai M, Yadav A andGade A (2009), Silver nanoparticles as a new generation of antimicrobials, Biotechnology advances, 27(1): 76-83.

[27] Raveendran P, Fu Jand Wallen SL (2003), Completely "green" synthesis and stabilization of metal nanoparticles, Journal of the American Chemical Society, 125(46): 13940-13941.

[28] Richardson SD, Plewa MJ, Wagner ED, Schoeny R andDeMarini DM (2007), Occurrence, genotoxicity, and carcinogenicity of regulated and emerging disinfection by-products in drinking water: a review and roadmap for research, Mutation Research/Reviews in Mutation Research, 636(1): 178-242.

[29] Roy SW, Mukherjee TR, Chakraborty, SHand Das TK (2013), Biosynthesis, characterisationand antifungal activity of silver nanoparticles synthesized by the fungus Aspergillus foetidus MTCC8876, Digest Journal of Nanomaterials and Biostructures, 8(1): 197-205.

[30] Sharma VK, Yngard RA and Lin Y (2009), Silver nanoparticles: green synthesis and their antimicrobial activities, Advances in colloid and interface science, 145(1-2): 83-96.

[31] Sondi I and Salopek-Sondi B (2004), Silver nanoparticles as antimicrobial agent: a case study on E. coli as a model for Gram-negative bacteria, Journal of colloid and interface science, 275(1): 177-182.

[32] Vigneshwaran N, Kathe AA, Varadarajan PV, Nachane RP andBalasubramanya RH (2007), Functional finishing of cotton fabrics using silver nanoparticles, Journal of nanoscience and nanotechnology, 7(6): 1893-1897.

[33] Wei C, Lin WY, Zainal Z, Williams NE, Zhu K, Kruzic AP and Rajeshwar K (1994), Bactericidal activity of $\mathrm{TiO}_{2}$ photocatalyst in aqueous media: toward a solar-assisted water disinfection system, Environmental science \& technology, 28(5): 934-938.

[34] Yamanaka M, Hara K and Kudo J (2005), Bactericidal actions of a silver ion solution on Escherichia coli, studied by energy-filtering transmission electron microscopy and proteomic analysis, Applied and environmental microbiology, 71(11): 7589-7593.

[35] Yeole K, Kadam P and Mhaske S (2014), Synthesis and characterization of fly ash-zinc oxide nanocomposite, Journal of Materials Research and Technology, 3(2): 186-190. 